\title{
THE UTILITY OF COLLECTIVE SECURITY IN THE CONTEXT OF HUMAN SECURITY. THE YUGOSLAV \& SOMALI EXPERIENCES
}

\author{
SUNDAY E. N. EBAYE- Ph. $D^{1 *}$, AMIMI, PAUL BASSEY ${ }^{2}$ \\ *1,2 Peace \& Conflict Studies Unit, Centre for General Studies, Cross River University of Technology, Calabar, Cross \\ River State, Nigeria. ${ }^{* 1}$ GSM: 08027511954 / $07069757438,{ }^{2}$ GSM: 07067022616. \\ *E-mail: sundayebaye@yahoo.com
}

*Corresponding Author: -

E-mail: sundayebaye@yahoo.com

\begin{abstract}
: -
When one examines closely the record of performance/non-performance of the UNSC at the crucial moments of the postCold War era, where major issues of peace and security are involved, including cases of human security crises, one finds that there is almost always tragic dilatoriness and/or lamentable inactions. While the UN was formed to save succeeding generations from the scourge of war' the list of scourges is growing. The real threats to international peace and security are no longer confined to violations of state sovereignty. Rather, new assertions of nationalism and sovereignty have sprung up, and the cohesion of States has been threatened by interstate conflict, poverty, infectious disease and environmental degradation, internal violence; including civil wars, genocide, ethnic-cleansing and state-failures, weapons-of-mass-destruction; including chemical, biological, radiological and nuclear-weapons, terrorism, and transnational-organized-crime, discrimination, and massive violations of human rights. All representing international security threats beyond the scope of any one state to solve. While the concept of peace may be easy to grasp, that of international security is more complex, for a pattern of contradictions has arisen. What is more worrisome is that each of these challenges is in a complex relationship of inter-linkage with each other. This paper intends to look at the changing scope of security, in the new environment of growing inter-linkage between peace-security-and-development, and to take a critical look at the new concept of human security and its implications to the treatment of the issue of collective-security in the UN. Data collection was through content analysis and analysed using the quantitative chi-square scientific method. Findings revealed that there is no significant relationship between collective-security in the context of human security and the resolution of the Yugoslav and Somali crises. The nature of today's threats is such that no state, no matter how powerful, can unilaterally defend itself against these threats. These threats require global cooperation if they must be prevented. A situation where the UN appeared to be working together with a military-block to attain strategic objectives cannot guarantee international peace and security. The UN support for NATO occupation of former Yugoslavia is a negation of the UN-charter, and that the involvement of the U.S forces in the bombing of Somali, did not help the image of the UN as the UN consciously or unconsciously allowed itself to be manipulated by a world power, seeking universal hegemony. The paper recommends: Aggressive economic development- that must advance the causes of securitydevelopment-and-human-rights together. Debt relief- as debts prevent the debt ridded countries from investing in productivity, thereby breeding unemployment and thus provide a ready market for conflict perpetrators. Reform of the economic-and-social-council- since the issues of peace-security-and-development are so inseparably interlinked, the powers and functions of the UNSC should include those socioeconomic issues of refugees, displaced persons, health-such as HIV/AIDS, coronavirus, human rights violations, etc, threatening the basis of human-security. The paper concludes that the concept of security must undergo a major transformation from the traditional concept relating to protection against external threats to a State, to a much wider concept relating to the protection of human individuals against threats to their security as individuals.
\end{abstract}

\section{(다)( () (1)}




\section{INTRODUCTION}

Any event or process that leads to large-scale death or lessening of life chances and undermines States, as the basic unit of the international system is a threat to international Security. So defined, there are six clusters of threats with which the world must be concerned now and in the decades ahead: - Economic and social threats, including poverty, infectious disease and environmental degradation • Inter-State conflict • Internal conflict, including civil wars, genocide and other large-scale atrocities $\bullet$ Nuclear, radiological, chemical and biological weapons $\bullet$ Terrorism, and, $\bullet$ Transnational organized crime. (UNHLP Report, 2004: Synopsis, Part 2).

While calls to reform the United-Nations (UN) and refashion collective security towards ensuring human security are common (Urquhart, 1992, Bennett and Lepgold,1993, Russett and Sutterlin,1991, Luck and Gati,1992, Kupchan and Kupchan,1991, Boutros-Ghali,1993), few substantive proposals have so far been made, save for some new guidelines by scholars on when to support U.N in the maintenance of international peace and security (The Los Angeles Times-May 6 and May 23,1994). The United-Nation-High-Level-Panel (UNHLP) report speaks of a concept of comprehensive collective security, which is characterized by both new threat situations and new potential causes of threat. These threats are from States; as well as non-State actors, and to human security as well as State security. The primary challenge for the $\mathrm{UN}$ and its members is to ensure that, of all the threats threatening the international system, those that are distant do not become imminent and those that are imminent do not actually become destructive. This requires a framework for preventive action which addresses all these threats in all the ways they resonate most in different parts of the world.

The expansion of the security concept corresponds with a strong emphasis on the necessity for preventive measures. While the classic breach of the peace could be effectively met by repressive means, with new dangers, this is either no longer possible or the possibilities are limited. Because of global economic integration, if ever there were to be a nuclear attack by terrorists on New York City, in addition to the death and devastation that would occur in New York, the economic damage globally would run in trillions of dollars. Millions of people in the developing world would be pushed either further into poverty or below the poverty line. Given the relationship that exist between intense poverty and infant mortality, there would be two death tolls - the first in New York from the physical attack itself, and the second would be a hidden death toll throughout the developing world.

However, most of these threats, including poverty, environmental degradation, and disease cannot be ameliorated or relieved by the deployment of military force. Nor can they be prevented by a single institution, or organ of the international community, but only through coordinated deployment of various institutions and mechanisms.

The intent of this paper therefore, is to support the current almost universally recognised view under international politics that the United-Nation-Security-Council (UNSC) possesses broad authority both to defend the security of a state from external threat (including threats from non-state actors such as terrorist and criminal groups), to prevent and respond to serious human rights violations within a state, and in particular to take political, economic and military measures according to Chapter VII of the UN Charter (UN Doc. A/59/565; http://www.un.org/secureworld/ ).

As such, the paper makes an important contribution to a more coherent view of a question long disputed in international politics:

In signing the Charter of the United-Nations, States not only benefit from the privileges of sovereignty but also accept its responsibilities. Whatever perceptions may have prevailed when the Westphalia system first gave rise to the notion of State sovereignty, today it clearly carries with it the obligation of a State to protect the welfare of its own peoples and meet its obligations to the wider international community (UNHLP Report, para. 29).

The paper also intends to look at the changing scope of security, in the new environment of growing inter linkage between peace, security and development, and to take a critical look at the new concept of human security and its implications to the treatment of the issue of collective security in the UN.

\section{Conceptual Analysis}

The international community therefore faces new challenges in the search for peace. The absence of war and military conflicts among States does not in itself ensure international peace and security. The non-military sources of instability in the economic, social, humanitarian and ecological fields have become threats to peace and security. The UN membership as a whole, working through the appropriate bodies, needs to give the highest priority to the solution of these matters. (White, 1997:52)

As first conceived by the founders of the United Nations, the collective security system was like a "vintage wine" (Claude, 1971:247). The idea of collective security is basically a politico-legal concept. The charter of the U.N. especially the Preamble, and Articles 1 and 2 use the terminology- "international peace and security" (UN charter), which also means that international peace and human security could be guaranteed only through collective measures by all the member states of the organization. Article 1(1) of the Charter gives a clearer insight into the concept. It stipulates that the maintenance of international peace and security is to be achieved through effective collective measures for the prevention and removal of threats to peace and to bring about adjustment or settlement of international disputes or situations by peaceful means. To achieve this objective therefore, states are required to act, in conformity with the principles of justice and international law (Art. 26).

According to Albright, collective security is not another term for alliance. Rather, as the theory suggests, any nation within the regional or international system that commits aggression, imperils the peace, or grossly exceeds the bounds of civilized behavior, violates the norms of that collective security system. She observed that, the international system faces a threat that:

...only collective security can ultimately manage...a world where weapons of mass destruction proliferate and ethnic and regional conflicts trigger 
massive refugee flows, enormous economic dislocations, unacceptable human rights atrocities, environmental catastrophes, and the senseless killing and maiming of millions of civilians (Albright,1993:65).

Only the international community has the collective moral authority and the physical and financial resources to redress all the grievances that flow from the end of the cold war. For the purpose of equity, if the UNSC is to speak and act on behalf of the entire world community, its efforts cannot be confined to only those issues of greatest consequence to its richer members.

Despite the Charter provision, it is clear that the concept of collective security, like so many others in current usage, has tended to lose specific meaning as a result of its being applied to many dissimilar arrangements. This position is corroborated by Fredrick Hartman, who asserted that, originally collective security meant that 'all nations could be secured if all were guaranteed their territorial integrity and existing political independence against external aggression by any state or states"(Hartman,1978;15).

There are many definitions and discussions of what is meant by collective security. Unlike unilateral actions, very generally we can delineate this area of international relations as any collective action designed to defuse situations that endanger the peace or to combat threats to and breaches of the peace (Downs, 1994). Using UN Charter terminology, collective security can both promote the peaceful settlement of situations that endanger peace (Chapter VI - processes) and take action with respect to threats to the peace, breaches of the peace or acts of aggression (Chapter VII - action).

Much debate, then centres around the meaning of the terms such as threat to the peace, breach of the peace, and the more judgmental concept of aggression, which of course had not had any agreed definition of the offence of aggression (Antonopoulos, 2001).

Collective security, to Inis Claude, is the middle ground between two poles that are characterized at one extreme by anarchy and at the other by world government (Claude, 1971). Anarchy is described as every nation for itself, and world government is considered an unattainable ideal (Stromberg, 1965). If one applies a means/end analogy to a collective security system, collectivity is the means, security is the end, while the system is the institution to make the means serve the ends (Naidu, 1975).

In other words the means are credible threats of collective measures ranging from diplomatic boycotts, through economic pressures, to overwhelming force. The ends are characterized by peace and stability in the international community and the institution is the UN. Collective security therefore, is the security of all states, by all states, for all states, even nonmembers, and aimed at ensuring human security.

...Security is the absence of danger to the fundamental values of any nation... the absence of fear and uncertainty in individuals and in nations... the absence of the danger of aggression or domination and the absence of threats to sovereignty, territorial integrity, independence and selfdetermination...the absence of the danger of domination through the direct or implied use of military might, as well as through economic, financial and political means of control to dictate and use of human or natural potential of another country. Security is to be free from hunger, disease, ecological catastrophes and foreign exploitation of human and natural resources. Security has national, international and humanitarian dimensions - all of them encompassed by freedomfreedom from fear of all the forms of bondage that are widespread in the world and reported daily by the media (Golob in UNDoc- Global security, 1987: 51).

Scholars have opined that the UN today has two souls. While the first soul works to ensure that international peace and security prevails through collective security, the second soul furthers the promotion of human rights, justice and social progress. To accomplish these mandates, each soul employs different strategies. While the second soul furthers the rights of mankind through consensus, treaties, committees and, occasionally economic and diplomatic pressure, the first soul must resort to coercive measures including military intervention in order to preserve the peace at all times (Boulden, 1993).

This work will explore both souls. If one reads the Charter of the UN, one finds that the founders were not averse to using force in order to deter aggressors and preserve international peace and human security. However, while the UN was formed to "save succeeding generations from the scourge of war" (Preamble of the UN Charter, 1945), the list of scourges is growing. The real threats to international peace and security are no longer confined to violations of state sovereignty for which the UN collective security system was created. Rather, genocide, massive violations of human rights, terrorism, weapons of mass destruction, among others represent immediate, international security threats that are beyond the scope of any one state to solve.

A forum through which states can act in common to ensure that international peace is maintained seems even more relevant today than it was some eight decades ago.

\section{Theoretical Analysis}

The theoretical foundation upon which this paper is laid, is the system theory. This is because it lays emphasis on the dialectical relationship between seemingly different elements. This helps us to reinforce the obvious fact that although there are different people living in different nations, yet our world is a global village where threat to the security of one nation also poses a threat to the entire global system. 
According to the system theory, a political system is a set of elements which are interrelated and interdependent, and comprises patterns of behaviours in dynamic interactions. These patterns of behaviours are generally all-inclusive in character and produces results that are authoritative and binding, and which enhances the peace prospects of the system objectives (Easton, 1965; Wiseman, 1966).

This theory could be traced to scholars such as Ludwig Von Bertallanfy - 1965, Gabriel Almond - 1965, David Easton 1965, Oran Young - 1968, among others. It posits that the world is a system of an organized whole in a dynamic interaction, and that by creatively constituting parts or sub-systems and structures into a system, the sub-systems become specialized units. These units are incapable of fulfilling by themselves all the separate functions needed to ensure their increased stability or homeostasis. They therefore depend on one another and it is this dependence that gives rise to rules which bind the system together.

Accordingly, every system aims at providing the ideal and appropriate environment for its parts or sub-system. Once the correct environment is established, the sub-systems act in ways that are beneficial to the maintenance of the system: survival, stability or homeostasis. But if the correct environment is lacking, the system will act in ways which move towards the disintegration of the system.

In collective security arrangements, actors identify each other as citizens who are obliged to uphold agreed-upon rules of behavior and act collectively to punish those who do not uphold those rules. There is no presumption that actors will universally agree to the directive-rules; an enforcement mechanism that includes military force is thus needed to punish any transgressors of the rules. A collective security arrangement may enforce only the rule of state sovereignty, or it could enforce rules regarding weapons proliferation, terrorism, human rights, among others. The use of force is considered to be sometimes necessary and acceptable to enforce system rules (Wendt, 1999).

Collective security orients actors to act as a system with a sense of duty to generate rules of peaceful behavior and punish those who break the rules. Through the explosion of multilateral treaties, UNSC resolutions and UN peacekeeping missions, actors have been slowly institutionalizing an international collective security arrangement in the post-cold war period. In the collective security, actors identify each other as friends committed to the peaceful resolution of conflict. Actors in the security system have a strong consensus about the obligation to follow the rules of their system, and they engage in peaceful, multilateral decision-making to ensure security through political relationships. The directive to follow the rules of the system does exist in the security system, but enforcement does not include the possibility of force. Given the lower level of threat in these social arrangements, security often refers to alternative security issues like the environment and the economy (Adler \& Barnett, 1999). The security system orients actors to act with great trust and togetherness toward others.

\section{COLLECTIVE SECURITY IN THE CONTEXT OF HUMAN SECURITY}

Human security in its broadest sense embraces far more than the Absence of violent conflict. It encompasses human rights, good governance, access to education and health care and ensuring that each individual has opportunities and choices to fulfill his or her potentials. Every step in this direction is also a step towards reducing poverty, achieving economic growth and preventing conflict. Freedom from want, freedom from fear, and the freedom of future generations to inherit a healthy natural environment. These are the interrelated building blocks of human security and therefore national security (Annan in UN Doc SG/SM/7382, 2000).

The former UN Secretary General- Koffi Annan, among other scholars have argued that the comprehensive nature of security include, human security, as this now joins the main agenda items of peace, security and development.

The end of the Cold War has come to witness another development which is going to pose a serious new challenge to the international community. Developments in humanitarian crisis in different parts of the world have come to create a new type of threat, against the background of the emergence of failed States, as well as the normative development in the consolidation of human rights and in the criminalization of genocide and other human atrocities. This is a different type of threat to peace and security in the international community which had not been envisaged in 1945, under the collective security system provided for in Chapter VII.

The demise of a world divided by the rivalry between two camps in confrontation, has ushered in a new era in which exogenous forces, that used to work for keeping nations in unity have disappeared and in its stead, indigenous forces that tend to work for disrupting the social fabric of society and disintegrating society itself have been unleashed. The result is that the solid basis for fostering the body politics of a nation in cohesion and for consolidating the system of governance in society has not been allowed to develop.

Thus in many of the newly created nation States, the social solidarity to be built on the basis of growth in the shared sense of belonging to one nation, either did not come to flower, or did come to collapse, thus creating a situation of failed States. It therefore becomes clear that the issue of development, which should comprise at its core the problem of nation-building, can no longer remain within the conventional realm of economic development to be measured by such criteria as the growth in income per capita of individuals, or the wealth of a nation in terms of the size of its GNP.

The time has come when development, hitherto defined in terms of the issue of freedom from want, has to be looked at, as an issue inseparably linked with the issue of security in terms of freedom from fear. It is through this linkage that the problem of human security has come to be regarded as part and parcel of the problem of collective security.

The concept of human security consists in the protection of the vital core of all human lives in ways that enhance human freedoms and human fulfillment. Human security can thus be said to comprise- protecting people from critical (severe) and pervasive (widespread) threats, and situations, using processes that build on people's strengths and aspirations, creating political, social, environmental, economic, military, and cultural systems, that together give people the building blocks of survival, livelihood and dignity ( UNCHS Report, 2003:4). 
The collapse of the Cold War order has unleashed forces, which have their origin very often in religious, racial, ethnic, and other social tensions, as well as inequity and other grievances in society, political and social alienation, and extreme poverty, giving rise to numerous civil wars and armed conflicts in many parts of the world. Moreover, what is important in this situation is that each of these challenges is in a complex relationship of inter linkage with each other.

In order to overcome these direct threats to the life and security of people who suffer from such dire conditions, it is not enough to deal with each of these threats separately, treating some as developmental issues in the technical sense, while treating others as security issues in the conventional sense.

In this situation, the concept of security itself has to undergo a major transformation from the traditional concept relating to protection against external threats to a State, to a much wider concept relating to the protection of human individuals against threats to their security as individuals. What is required under such circumstances is to build a social framework in which individuals can empower themselves so that they can live free from want, and free from fear. In order to achieve this, the strategy should include addressing those diverse threats in a comprehensive manner as the issue of human security, capturing the inter linkages among them from a human perspective.

This strategy is bound to have some substantive implications to the way in which the UN is to be organized from a structural point of view, as well as the way in which it is to function from an operational point of view.

In over seven decades, of the founding of the UN, the world has changed dramatically. Attempts have been sought to maintain the essence of collective security, and broaden it to include threats that go far beyond aggression by states. Such as- (i) Interstate conflict, (ii) Poverty, infectious disease and environmental degradation (iii) Internal violence; including civil wars, genocide, ethnic cleansing and state failure, (iv) Weapons of mass destruction; including chemical, biological, radiological and nuclear weapons (v) Terrorism, and (vi) Transnational organized crime.

This paper underscores three conceptual points. The first is that we live in an era of an unprecedented interconnection of threats. Second, there is an unprecedented mutual vulnerability between the rich and the poor, and the weak and the strong. Third, the nature of today's threats is such that no state, no matter how powerful, can unilaterally defend itself against these threats. All of the threats if they are to be either prevented or responded to, require global cooperation.

The biological security of the United States or Europe is dependent on the ability of the poorest countries to monitor, respond to, and contain, an emerging infectious disease.

Over the last three decades, we have seen the spread of infectious diseases such as: HIV/AIDS, SARS, etc. The incubation time of many deadly infectious diseases is longer than the average international flight time, which means, any one of the millions of annual air passengers could be an unwitting carrier of a deadly infectious disease.

The amount of highly enriched uranium that it would take to create an improvised nuclear device could fit in one-liter milk cartons. If terrorists were ever to get their hands on that much highly enriched uranium, they would probably have no problem in getting it into a country to create a nuclear device. This issue urgently requires cleaning up highly enriched uranium around the world, revising the nonproliferation regime to create incentives for states to forego the development of domestic uranium enrichment and reprocessing facilities, and strengthening the capacity of states throughout the world to exert better border control.

As convincing as the comprehensive concept of international human security may be, it has its problematic sides. Some critics see the emphasis of traditional development goals (the fight against poverty and disease; environmental protection) as merely a rhetorical gesture to the developing countries of the South, in an attempt to tie their specific agenda into the report and win them over to its overall aims. Others see the categorization of these development goals as security issues, and as a kind of trick to try and persuade the governments and the public of industrialised nations, particularly the USA, to increase development cooperation and the financial means expended on it, not as a means in itself (which they would presumably not be prepared to do) but because it would be likely to guarantee their own security.

As with the concept of human security, critics of the all-encompassing concept of international security contend that the external security of a country like the US, or Germany is only very indirectly threatened by poverty and underdevelopment in the southern hemisphere, and that it is therefore incorrect to place these threat situations on the same level as inter-state wars, civil wars, and terrorism.

To equate poverty, disease, environmental degradation, and organized transnational crime as threats to world peace and international security, would necessarily lead to the recognition of corresponding powers of the UNSC under Chapter VII of the UN Charter. The UNSC would, for example, in the event of serious violations or degradation of natural environmental resources in a State, or in the case of the persistent refusal of a government to combat poverty in a suitable and viable manner, be able to take non-military or even military measures against the country in question.

The authors of the UNHLP report, in dealing with the fight against HIV/AIDS for instance, say that the UNSC, and UNAIDS should hold a second special session on HIV/AIDS as a threat to international peace and security, to improve recognition of the problem, and develop a long-term strategy to minimise the threat. By adopting a half-hearted position on these new dangers; not, however, the danger of terrorism, genocide and serious human rights violations, it adheres implicitly to a determination of threats to world peace according to the standards of military-policing security.

The mechanism for dealing with issues concerning international peace and security is laid down in Chapters VI and VII of the UN Charter. Chapter VI encourages the parties to a conflict to solve their dispute through peaceful means such as mediation, negotiation, arbitration, and judicial settlement (article 33), without undermining the authority of the UNSC, since article 34 of the Charter empowers the UNSC to investigate any dispute, or any situation which might lead to international friction or give rise to a dispute, in order to determine whether the continuance of the dispute or situation is likely to endanger the maintenance of international peace and security.

It should however be noted with much emphasis that, law is the conscience of morality. It is the basis of international peace and security. It is the foundation of justice. Thus, if nations submit to the jurisdiction of the international law, many 
problems will be resolved without bloodshed, and the maintenance of international peace and human security can be guaranteed through collective security.

\section{Methodology and Analysis 5.1Research design}

This sub section deals with the analysis of the principles of methods, rules, and postulates employed in carrying out this research. It is concern with the systematic study of the method that has been applied, the rationale and the philosophical assumptions that underlie this study.

\subsection{Area of study}

\section{(i) Somalia}

According to Lewis (1995), the Somali people; with a population of 4,000,000 (plus 500,000 in Kenya) practices the Islamic religion and inhabits almost the entire Horn area of Africa. Majority of the Somali people live in the country of Somalia, and are also the principle inhabitants of the Ogaden region of Southeastern Ethiopia. Somalis also live in the Southern half of the country of Djibouti, and in the North Eastern Province of Kenya. The Digil and Rahawiin (Reewiin) clans, who speak the Maay language, and the Jiiddu and Tunni, speaking their Maay-related languages, are also part of the broader Somali clan structure and political alliances. These clans include an additional 1.5 million people whose distinct characteristics warrant classifying them as separate ethnic groups. The Somalis are most closely related to the Rendille and the Afar, and distantly related to the Oromos, all Eastern Cushite people. Somalis are not a unitary people group, but a grouping of broad clan federations divided by language and clan conflicts. Although all Somalis profess strong allegiance to Islam, they hold stronger primary loyalties to self, family and clan, in that order (Lewis, 1995).

\section{(ii) Yugoslavia}

Like the Kingdom of Yugoslavia that preceded it, the socialist Federal Republic of Yugoslavia (SFRY) bordered Italy and Austria to the Northwest, Hungary to the Northwest, Romania and Bulgaria to the East, Greece to the South, Albania to the Southwest, and the Adriatic Sea to the West. The most significant change to the borders of the Socialist Federal Republic of Yugoslavia occurred in 1954, when the adjacent Free Territory of Trieste was dissolved by the Treaty of Osimo. The Yugoslav Zone B, which covered $515.5 \mathrm{~km}^{2}$, became part of the Socialist Federal Republic of Yugoslavia. Yugoslavia was formed under the name Kingdom of Serbs, Croats and Slovenes. In January 1929, King Alexander I assumed dictatorship of the country and renamed it into Kingdom of Yugoslavia, for the first time making the term 'Yugoslav', which was used colloquially for decades (even before the country was formed), the official name of the state (Benson, 2001). After the Kingdom was occupied during World War II, the new Yugoslav state was proclaimed in 1943 and named Democratic Federal Yugoslavia, with its name leaving the question of republic or kingdom open. In 1946, it became the Federal People's Republic of Yugoslavia (Benson, 2001) and in 1963 the Socialist Federal Republic of Yugoslavia. The state is most commonly referred to by this last full name (Socialist Federal Republic of Yugoslavia), which it held for the longest period of all.

The population of Yugoslavia spoke three languages, Serbo-Croatian, Slovene and Macedonian. The Serbo-Croatian language was spoken by the population in the federal republics of SR Croatia, SR Serbia, SR Bosnia and Herzegovina, and SR Montenegro - a total of 12,390,000 people at that time. Slovene was spoken by approximately 1,400,000 inhabitants of SR Slovenia, while Macedonian was spoken by 931,000 inhabitants of SR Macedonia. National minorities used their own languages as well, with 506,000 speaking Hungarian (primarily in a part of SAP Vojvodina), and 780,000 persons speaking Albanian in SR Serbia and SR Macedonia. Turkish, Romanian, and Italian were also spoken to a lesser extent.

In 1992, the Socialist Federal Republic of Yugoslavia's territory disintegrated as the independent states of Slovenia, Croatia, Republic of Macedonia and Bosnia and Herzegovina separated from it, though the Yugoslav military controlled parts of Croatia and Bosnia prior to the state's dissolution. By 1992, only the republics of Serbia and Montenegro remained committed to the union, and formed the Federal Republic of Yugoslavia (FRY) in 1992. The full official name of the country, however, varied significantly between 1943 and 1992 (Benson, 2001).

\section{- Method/Source of data collection}

The data for this research were collected through the survey of available relevant literature and scholarly contributions on the Yugoslav and Somali crises, arising from conferences, discussants, and publications on these crises.

\section{- Method of data analysis}

The content analysis design was adopted in this research. Content analysis as a methodology in the social sciences is a type of secondary data analysis that is used to analyse text, including newspapers, books, journals, manuscripts, and web sites to determine the frequency of specific ideas (Krippendorff, 1980). Here, it is used to analyse the place of collective security in the context of human security in the international system, particularly as it relates to the Somali and Yugoslav crises.

However, the content analysis as used here was supported with the chi-square method in order to scientifically test the weighted scale result. The aim is to ensure the deductions of generalizations that provide the basis for making tested postulations. 


\section{Testing of hypotheses}

The hypothesis upon which this paper is premised is cast in the null form:

\section{Hypothesis}

$\mathrm{H}_{\mathrm{o}}$ : There is no significant relationship between collective security in the context of human security and the resolution of the Yugoslav and Somali crises.

$\mathrm{H}_{\mathrm{i}}$ : There is significant relationship between collective security in the context of human security and the resolution of the Yugoslav and Somali crises.

In the above hypothesis, the "collective security" is the dependent variable, while the "Yugoslav and Somali crises" is the independent variable.

This relates to the indicators of the collective security in the context of human security and the Yugoslav and Somali crises. Where available data show that the collective security was not significant in the resolution of the Yugoslav and Somali crises, the null hypothesis will be accepted and alternate hypothesis will be rejected. While the alternate hypothesis will be accepted, and the null hypothesis rejected where the available data show that the collective security was significant in the resolution of the Yugoslav and Somali crises. Available data from the surveyed literature indicate as follows:

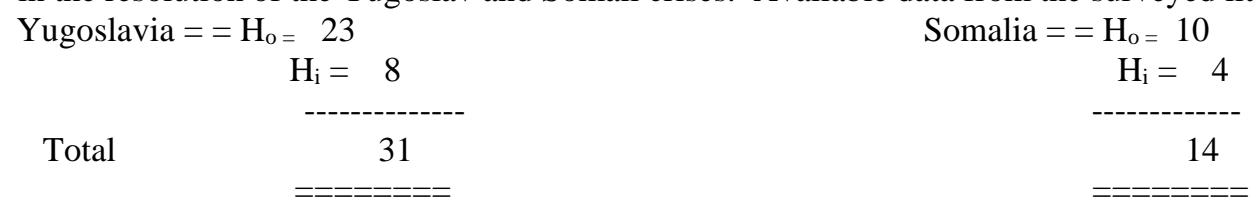

Having used content analysis in the presentation of data as shown above, the chisquare method of data analysis shall be adopted to scientifically test the weighted scale.

\section{TABLE 5.5}

Chi-square analysis of the relationship between collective security in the context of human security and the resolution of the Yugoslav and Somali crises

\begin{tabular}{|c|c|c|c|c|}
\hline ARTICLES & $\begin{array}{c}\text { ALTERNATE } \\
\text { HYPOTHESES } \\
\text { (Hi) }\end{array}$ & \multicolumn{2}{|c|}{$\begin{array}{c}\text { NULL } \\
\text { HYPOTHESES } \\
\text { (Ho) }\end{array}$} & TOTAL \\
\hline YUGOSLAV & 23 & \multicolumn{2}{|c|}{8} & 31 \\
\hline SOMALIA & 10 & \multicolumn{2}{|r|}{4} & 14 \\
\hline TOTAL & 33 & \multicolumn{2}{|r|}{12} & 45 \\
\hline Of & $\mathrm{Ef}$ & $\begin{array}{c}\text { Of - } \\
\text { Ef }\end{array}$ & (Of-Ef) & $\frac{(\mathrm{Of}-}{\frac{\mathrm{Ef})^{2}}{\mathrm{Ef}}}$ \\
\hline 238 & 22.73 & 0.27 & 0.07 & 0.003 \\
\hline 10 & 8.27 & -1.27 & 1.60 & 0.20 \\
\hline 4 & 10.30 & -0.30 & 0.09 & 0.09 \\
\hline & 3.73 & 0.27 & 0.07 & 0.02 \\
\hline
\end{tabular}

Chi-square formula $=\mathrm{X}^{2}=\sum \underline{(\mathrm{Of}}-\underline{\mathrm{Ef}}^{2}$ and 0.05 as critical value

Where $\sum=$ Summation

\section{$\mathrm{Ef}$}

Of $=$ Observed frequency

$\mathrm{Ef}=$ Expected frequency

Degree of freedom $(\mathrm{df})=(\mathrm{N}-1)(\mathrm{C}-1)$ where $\mathrm{N}=$ number of category, and $\mathrm{C}=$ number of columns. From table 5.3 therefore:

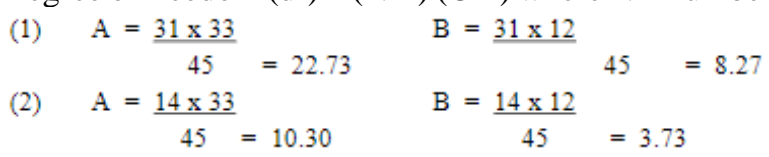

Degree of freedom $(\mathrm{df})=(\mathrm{N}-1)) \mathrm{C}-1)=(2-1)(2-1)=1 \times 1=1$

Critical table value $=0.05$

Computed $\mathrm{X}^{2}$ value $=0.31$

Using $\mathrm{X}^{2}$ table, $\mathrm{df}=1$ under $0.05=3.84$

Therefore, since the computed $X^{2}$ value of 0.31 is less than the critical table value at 0.05 of 3.84 , the alternate hypothesis (Hi) which states that there is significant relationship between collective security in the context of human security and the 
resolution of the Yugoslav and Somali crises is rejected. While the null hypothesis (Ho) which states that there is no significant relationship between collective security in the context of human security and the resolution of the Yugoslav and Somali crises is hereby accepted and upheld.

An evaluation of the above clearly reveals the following findings:

Even though the Government of the former Federal-Socialist-Republic-of-Yugoslavia invited the UNSC, to assist in restoring peace, the UNSC, did not do this with utmost honesty.

That the constitutional arrangements for Bosnia-Herzegovina were not aimed at dividing Yugoslavia, but rather to give autonomy to the region.

That the role of the UN' forces in Yugoslavia saw the UN compromise its neutrality, thus rendering its efforts incapable of resolving international conflicts.

That the embargos, the partiality of the European-Community-Monitoring-Mission, and the hurried admission of the republics that make-up the former Federal-Socialist-Republic-ofYugoslavia, fueled the embers of injustice and conflict and left deep sore in the minds of honest men is not in doubt.

That a situation where the UN appeared to be working together with a military block to attain strategic objectives cannot bring international peace and security. Therefore, the work still considers the UN support for NATO occupation of former Yugoslavia as a negation of the UN charter.

In the case of Somalia, the paper observed that the UN consciously or unconsciously presented itself; on a platter of gold, as an instrument for attaining the strategic objective of a mega power - the U.S.

Even the press statement by the President of the UNSC on June 14, 1993, expressing deep regrets for the casualties suffered by the civilians as a result of June 13, incident during which many Somali were said to have been killed by the UNOSOM II forces, could not soften the already antagonistic posture of Somali against UNOSOM II forces.

The UN, in blaming General Aidid and his supporters for using women and children as human shields to screen attacks on fixed guard posts of strong points, showed that the UNOSOM II forces in Somalia had mismanaged an already bad situation by taking sides (UN Dept of Infor., 1994).

The UN should have maintained dignified neutrality, so that it could deal with the situation effectively in spite of the provocation. The inability of the UN to adopt this posture led to distrust, and its inability to disarm some clan leaders and the opposition, as provided for by the Addis Ababa agreement and mandated also by the UNSC.

The coercive disarmament program which started in October 1993, whereby UNOSOM II forces actively patrolled the roads, forcefully disarming combatants of USC/SNA, and confiscating their weapons, using loud speakers, presented UNOSOM II forces as participants in the Somali political process, indeed as one of the political parties. Its arrest of mainly opposition faction members presented the picture of a body determined to install one faction in power.

The deployment of the U.S Rangers, and its Quick Reaction Forces in Mogadishu, in support of UNOSOM II operation, under the control of the United States, worsens the situation in the country. With the vengeance of a world power losing control over its strategic areas, it pounded civilian targets as a reprisal of those who were suspected of complicity in the June 5, attack, as well as subsequent attacks on UN personnel, and facilities (UN Dept of Infor., 1994).

It must be noted that the involvement of the U.S forces in the bombing of Somali, did not help the image of the UN as the UN consciously or unconsciously allowed itself to be manipulated by a world power, seeking universal hegemony.

The misuse of power by the UN Secretary General, cannot also escape our comment.

Just as the involvement of NATO worsen the situation in the former Yugoslavia, the UnitedStates involvement in the Somali war totally destroyed any basis for the restoration of confidence.

There is no doubt that the arrest of key aides to General Aidid was provocative and had serious reactions. Thus:

The operation succeeded in apprehending 24 suspects, including two key aids to General Aided. During the course of the operation, two US helicopters were shot down by Somali militiamen using automatic weapons and rocketpropelled grenades. While evacuating the 24 USC/SNA detainees, the Rangers came under concentrated fire. Eighteen US soldiers lost their lives and 75 were wounded. One US helicopter pilot was captured and subsequently released on 14 October 1993. The bodies of the US Soldiers were subjected to humiliating treatment (UN Dept of Infor., 1994:13).

It is important at this stage, to state also that the UN Secretary General should have carried out a comprehensive ideological, ethnic, and religious leaning of the parties, and not just the newspaper-type of assessment. If he had thoroughly done this with the assistance of African experts in the field, instead of acting on the prototype assumption of "we know the Somalis", he could have been able to unlock the apparently hardened minds of the Somalis. A critical evaluation of the above, shows a narrow based analysis of a complex situation based on hear-say, and not a comprehensive intellectual evaluation.

The ideological legacy left behind by Barre, and the nostalgia to return to the past cannot be overlooked. Nothing was said about the great powers using one group against the other. For Mr. Ali Mahdi and General Aidid to have locked themselves in such a war, there must be irreconcilable and mutually opposed ideological contradiction which leads to a war of attrition as it was the case in Somalia.

\section{Summary, Conclusion And Recommendations.}

...the Security-Council is fully empowered under Chapter VII of the 
Charter . . to address the full range of security threats with which States are concerned and that therefore the task is not to find alternatives to the UNSC as a source of authority but to make the Council work better than it has (UNHLP Report, para. 198,).

Consistent with the results of globalisation research, this paper draws attention to the growing interdependence of States, and to issues of human security in the international system. The sovereignty of States is understood not just as the right to autonomy but also as responsibility for the well-being of the State's people, as well as that of other peoples. Effectiveness, efficiency, and fairness, are described as basic elements of a credible system of collective security. To attain Collective security, and meet the challenge of prevention, individual categories of threats to international security, in the broad sense, will be met with preventive measures. This work lists the main threats to peace as poverty, infectious diseases, and environmental degradation. Then, follow as causes or sources of further threats to peace: weapons of mass destruction (nuclear, radiological, chemical, and biological weapons), terrorism, and transnational organized crime. With the two last named categories, the research also recognises the dangers emanating from nongovernmental actors as threats to world peace, and international security under the terms of the UN Charter.

The paper observed that in the course of the development of human society, especially ever since social antagonism evolved from the womb of class differentiation, mankind has witnessed one form of conflict or the other. Some are local in nature, while others are regional or even universal. This differentiation notwithstanding, a seemingly local conflict might lead to global conflict capable of threatening international peace and security.

In the early days of the UN Charter, threats assumed to be limited to states bent on war. The appropriate action was a collective response of a threat of violent force to counter the aggressor, and deter future aggressors.

So long as power is diffused amongst the states, and states are willing to cede sovereignty to the collectivity, then collective security would ensure the safety and security of the world order. This, however, is an ideal position, and rarely is it a realistic one.

Since the number of intrastate conflicts has increased, many have suggested that, what constitutes a threat to international peace and security be reexamined. War is no longer the main preoccupation of states. Rather, poverty, infectious diseases, weapons of mass destruction, and terrorism are "the gravest threats to the world's survival and well-being of individuals" (UNHLP Report, 2004: para.12).

In this context, this paper seeks to make some preliminary suggestions as to what changes should be made, to ensure the effective functioning of the UN.

The interpretation of the Charter, upon which the role of the UN rests, and the actions of the UNSC must flow from the collective will, not from the views, or predilections of a few.

The paper suggests a wider representation in the UNSC, to ensure its moral sanction and political effectiveness. The Council should anticipate the consequences of its decisions, and take speedy action to address problems arising in a third country from their implementation. For example, economic sanctions against one country could have a major impact on its trading partners. Therefore, while acknowledging the obligations of the State to protect human rights, this paper suggest that there is a need to delineate the parameters that harmonized the defence of national integrity with respect for human security.

\section{Recommendations.}

After the final destruction of the...tyranny, they hope to see established a peace which will afford to all nations the means of dwelling in safety within their own boundaries, and which will afford assurance that all the men in all the lands may live out their lives in freedom from fear and want (UNDoc.A/59/2005 http://www.un.org/largerfreedom ).

Though the political debates now going on within the UN sometimes tend to reflect individual national priorities, and political aspirations based largely on parochial interests of different member States, rather than the genuine concern of the member States about the viability of the UN system from the viewpoint of public order in the international system, this paper make bold to present the following recommendations.

\section{(i). Economic Development}

The world must advance the causes of security, development and human rights together, otherwise none will succeed. Humanity will not enjoy security without development, it will not enjoy development without security, and it will not enjoy either without respect for human rights (UNDoc. Executive summary, A/59/2005; http://www.un.org/largerfreedom).

Without economic development and prosperity, lasting peace and stability would not be achieved. Equally, however, only when conditions of security and peace are assured could sustained economic development take place. According to Prof. Celestine Bassey:

The multiple and unabated economic crisis in the African continent has been generally linked in recent times to the unsettled conditions of widespread civil disorder and the accelerated syndrome of failed states in Africa. In existential terms, the immanent linkage between conflict and underdevelopment crisis is nonlinear, but dialectical. Underdevelopment crisis breeds conflict, and conflict in turn sustains the quagmire of economic crisis in Africa. In this regard, any strategy for economic development (and the maintenance of human security) which fails to integrate the broader social conditions of Africa (and the world) is to say the least emasculated (Bassey, 2007:xv). 
Development is the first line of defense for collective security. For development is the antidote to the most pressing human security threats, including poverty, infectious disease, and environmental degradation, each of which kills millions every year.

Secondly, development is absolutely crucial for creating states that have the capacity to exercise their sovereignty responsibly. In the end, any collective security system is only as good as the capacity of its constituent states.

Thirdly, given what we now know about the relationship between poverty and onset of civil war, development is the best medium- to long-term strategy for the prevention of deadly conflict.

\section{ii). Debt Relief}

We identified foreign debts by the developing countries as part of the problems facing mankind today. It is our innermost conviction, that debts are threats to international peace and security because, debts prevent the debt ridded countries from investing in productivity, thereby breeding unemployment and thus provide a ready market for conflict perpetrators. This also create problems for the developed countries as many of those unemployed people immigrate to these countries as both economic and political refugees, thereby creating social conflicts and the revival of neo-fascist groups in such countries.

We recommend that part of the money that should have been used for armament should be used for debt relief. In other words, that the money should be re-circulated to pay off the debts of the developing countries, especially now that most of the debts are neither payable nor collectable.

\section{iii). Reform Of the Economic And Social Council (Ecosoc)}

The last time that ECOSOC was reformed, was to provide for the increase in the UN membership, particularly the newly independent States of Africa and Asia. However, that reform focused mainly on the expansion of its membership, and as a result, even led to some loss in the effectiveness of this organ.

Given the new developments in the post-Cold War situation, where the issues of peace, security and development have come to be so inseparably interlinked, and where the issues relating to human security are so inevitably part and parcel of the activities of the UNSC, as well as those of the ECOSOC, much more basic reform in the structure of the UN in this area would seem to be as important as the reform in the functioning of the UNSC.

Firstly, it is essential to realize on the one hand, that in light of these new developments, the powers and functions of the UNSC, in an operational sense, should extend to those socioeconomic issues which traditionally have not been regarded as falling within the jurisdiction of the UNSC. These issues include the issue of refugees and internationally displaced persons, the issue of health- such as HIV/AIDS, among others, the issue of human rights violations, and many others directly threatening the very basis of human security, all of which fall within the category of the issues relating to the public order of the international system.

Secondly, this however should not mean on the other hand that the power and functions of the UNSC in this area can be exclusive or even primary, in relation to other organs of the UN, and in particular the ECOSOC. On the contrary, a major overhaul of the ECOSOC itself should be undertaken as the primary organ in this field, on the basis of a fundamental rethinking of its roles and functions.

The UNHLP report has already recommended the establishment of a Committee on the Social and Economic Aspects of Security Threats, and the creation of a Peace building Commission under the UNSC, which nevertheless should include representation from the ECOSOC.

What is needed to achieve the purpose of strengthening the capacity of the UN in this field is a holistic approach, which should mobilize into the process of policy formulation and implementation by all the stakeholders.

\section{iv). The Role of The International Court Of Justice (Icj)}

With regards to the role of the ICJ, the importance of the rule of law in the international system as the basis for international peace is self-explanatory. Needless to say, the rule of law is not the monopoly of the ICJ, as one can easily see from the fact that there are so many other international courts, tribunals, and other quasi-judicial organs, such as: International Chambers of Commerce (ICC), International Centre for Settlement of Investment Disputes (ICSID), International Commercial Arbitration Court (ICAC), International Council for Commercial Arbitration (ICCA), and World Trade Organisation (WTO). All these are dispute settlement mechanisms, that are functioning so competently in their respective specialized fields (Orojo and Ajomo,1999).

This paper expresses that, in the context of the emphasis that has been placed on the centrality of the UN in the present international system as the guarantor of international peace, the functions as well as the functioning of the ICJ should receive a more careful attention for review and study from the viewpoint of promoting the rule of law in the international system.

\section{v). The Question of The Access To The Icj}

This paper wishes to observe that it is becoming anachronistic to restrict the access to the ICJ only to States. The situation seems to have become even more serious in recent times, not only by the growing practice of participation by international organizations in some multilateral conventions as full-fledged parties and by their recognized capacity to act in their own right, going beyond their capacity to rights in the international arena. It is the view of this paper that a serious rethinking on this issue will likely contribute to the effective maintenance of international peace and collective security.

The duty of preserving international peace and human security is the collective responsibility of the entire mankind. The UN must live up to expectations, and not compromise its principles in the trying times of increased violence perpetrated 
by both states and non-state actors. The UN, must therefore continue to act; through its UNSC, as the chief guardian of the security of humans and nations, particularly the weak nations, and as a catalyst for the promotion of the primacy of the rule of law in international relations.

It is worthy to note that, though the UN has recorded tremendous successes in the attempt to delineate the antagonistic elements in conflict, there are still some areas that need to be addressed. The recommendations in this paper are therefore intended to bridge those vacuums.

\section{References:}

[1].Adler, E. \& Barnett, M. (1999). Security communities. Cambridge: Cambridge University Press.

[2].Albright, M. K. (1993a). The new opportunity to build a collective security system. Foreign Policy Bulletin, 4, 65-68.

[3].Albright, M. K. (1993b). A strong United Nations serves U.S. security interest. Dispatch, June 28, 461-462.

[4].Albright, M. K. (1993). Address to the national defense university. Washington D.C.: Fort McNair Federal News Service.

[5].Antonopoulos, C. (2001). Whatever happened to crimes against peace? New Delhi: Asia Publishing House.

[6].Bassey, C. O. (2007). Introduction: The nexus of conflict and development crisis in Africa. In Celestine Bassey and Oshita Oshita (Ed.), Conflict resolution, identity crisis and development in Africa. Lagos: Malthouse Press.

[7].Bennett, A. \& Lepgold, J. (1993). Reinventing collective security after the cold war and gulf conflict. Political Science Quarterly, 108(2), 213-233.

[8].Benson, L. (2001). Yugoslavia: A concise history. London: Palgrave Macmillan.

[9].Bertallenfy, L. V. (1965). General system theory. In D. J. Singer (Ed.). Human behaviour and international politics. Chicago: Rand McNally, 302-361.

[10]. Boulden, J. (1993). Cruise missiles and strategic arms control. Ottawa: Canadian Centre for Global Security.

[11]. Boutros-Ghali, B. (1993). The world can't have it both ways at once. The Irish Times, Aug. 21, 6.

[12]. Claude, I. L. (1971). Swords into plow shares: The problems and progress of international organization (4 ${ }^{\text {th }}$ ed.) New York: Random House.

[13]. Claude Jr., I. L. (2006). Collective security as an approach to peace. In Donald M. Goldstein, Phil Williams \& Jay, M. Sharfritz (Eds.) Classic readings and contemporary debates in international relations. Belmont CA: Thomson Wadsworth, 289-302.

[14]. Downs, G. W. (1994). Collective security beyond the cold war. Ann Arbor: Michigan University Press.

[15]. Easton, D. (1965). A framework of political analysis. Englewood Cliffs: Prentice Hall.

[16]. Hartman, F. (1978). The relations of nations (5 ${ }^{\text {th }}$ ed.). New York: Macmillan.

[17]. Kupchan, C. A. \& Kupchan, C. A. (1991). Concerts, collective security, and the future of Europe. International Security. 16. 114-161.

[18]. Lewis, I. M. (1995). Peoples of the horn of Africa. London: International African Institute.

[19]. Luck, E. C. \& Gati, T. T. (1992). Whose collective security? The Washington Quarterly. 3, 43-48.

[20]. Naidu, M. V. (1975). Collective security and /he United Nations. New York: St. Martin's Press.

[21]. Russett, B. \& Sutterlin, J. S. (1991). The U.N. in a new world order. Foreign Affairs, Spring. 70(2). 69-83.

[22]. Stromberg, R. N. (1965). The idea of collective security. In Joel Larus (Ed.), Collective security to preventive diplomacy: Readings in international organization and the maintenance of peace. New York: John Wiley \& Sons, 273-277.

[23]. The Guardian Newspaper, Oct. 20, 1995: 'NATO is Part of the Problem'.

[24]. The Guardian Newspaper, Sept. 15. 2009. Back page: 'The Somali Crisis'.

[25]. The Time Magazine. August 9, 1971 "Yugoslavia: Tito's Daring Experiment'.

[26]. United Nations (1987). General Assembly document: Global security for the $21^{\text {st }}$ century: proceedings of the UN symposium. Dec. New York: United Nations.

[27]. United Nations (1991). The UN and the situation in the former Yugoslavia. New York: United Nations Department Of Public Information.

[28]. United Nations (1994). The UN and the situation in Somalia. New York: United Nations Department Of Public Information. March.

[29]. United Nations (2000). General Assembly document SG/SM/7382: Press Release, May 8. New York: United Nations.

[30]. United Nations (2003). General Assembly document: Report of the commission on human security (UNCHS.) New York: United Nations.

[31]. United Nations (2004). United Nations high level panel (UNHLP): Report on Threats, Challenges and Change: A/59/565. A More Secure World: Our Shared Responsibility. December. Retrieved August 8, 2009. http://www.un.org/secureworld.

[32]. United Nations General Assembly (2005). General Assembly document A/59/2005: Executive summary. New York: United Nations. http://www.un.org/largerfreedom. Retrieved August 8. 2009

[33]. Urquhart, B. (1992). The U.N.: From peace-keeping to peace-making? Adelphi Paper, 265, 19-21.

[34]. Wendt, A. (1992). Anarchy is what states make of it: The social construction of power politics. International Organization. 46 (2), 391-425.

[35]. Wendt, A. (1999). Social theory of international politics. Cambridge: Cambridge University Press.

[36]. Wengraf, L. (2009). The nightmare in Somalia: Another US sponsored catastrophe, centre for research on globalization. Retrieved February 2, 2009 from www.counterpunch.org/wengraf. 
[37]. Wesley, M. (1997). Casualties of the new world order: The causes of failure of UN missions to civil-wars. Basingstoke: Macmillan.

[38]. White, N. D. (1997). Keeping the peace: The UN and the maintenance of international peace and security ( $2^{\mathrm{n}}$ ed.). Manchester: Manchester University Press.

[39]. White, N. D. (2000). The legality of bombing in the name of humanity. Journal of Conflict and Security Law, 5(1), 27-43.

[40]. Wiseman, H. V. (1966). Political system: Some sociological approaches. New York: Praeger. Zimmermann, W. (1995). The last ambassador: A memoir of the collapse of Yugoslavia. Foreign Affairs, 74 (2). Retrieved August 8 , 2009 from www.foreienaffairs.com/.. .zimmermann. 